\title{
Turkey censors evolution
}

\author{
Turkey's government has done more for science than many. A row over a censored \\ magazine and a sacked editor could put the good work at risk.
}

$$
\text { li }
$$
t has been the biggest crisis in Turkish academia since last year's lifting of the headscarf ban in universities. Last week a portrait of Charles Darwin was taken off the cover of the March issue of the government-backed science magazine Bilim ve Teknik (Science and Technology) just before it went to press. TÜBİTAK, Turkey's national science funding agency, which publishes the magazine, then sacked its editor, Çiğdem Atakuman. Scientists, assuming censorship, are justifiably outraged and protests are ongoing.

Science minister Mehmet Aydın, a historian of philosophy and religion, expressed discomfort at the cover's removal - but also fanned the flames by commenting: "What kind of a fight can we have with Darwin? The guy is already dead." He made matters worse by later adding: "[TÜBİTAK] is supposed to reflect the views of all those who have served science, no matter how mistaken they can be."

TÜBİTAK vice-president Ömer Cebeci, who sits on the magazine's editorial board, pulled the plug on Darwin. He denied censorship, charging that Atakuman had secretly changed an issue intended to cover global warming. Not true, says Atakuman, who says Cebeci told her that the Darwin cover was a "provocation" at a time of imminent local elections. One editorial-board member of Bilim ve Teknik has resigned in protest at what he, at least, considers censorship.

This row has brought into focus two issues that plague Turkish science. One is political interference in the scientific civil service; the other is high levels of public support for creationism.

In Turkey, as in many countries, the civil service is expected to mirror the ruling party's ideology. So, although they are keen funders of research, most senior government officials, in common with most of the population, do not believe in evolution by natural selection. The education minister Hüseyin Çelik, for example, has proclaimed his belief in intelligent design. Yet Turkey is one of three current

candidates for membership of the European Union (EU). Ankara and Istanbul house the largest overseas missions of the European Commission, whose officials are monitoring all aspects of Turkish public life and constantly advising on what needs to be done to harmonize laws and practices with those in the EU.

Science and technology was one of the first 'chapters' that the EU said it was satisfied with and that, provisionally, did not require further

"Although they are keen funders of research, most senior officials, in common with most of the population, do not believe in evolution." reform. Officials will now almost certainly be alarmed to see the extent of political interference in TÜBİTAK.

Only last week, the European Parliament issued a report stating that Turkey needed to make much faster progress in areas such as censorship. European officials will see this latest episode as evidence that the country has some way to go on that score.

TÜBİTAK needs to initiate a transparent investigation into the Bilim ve Teknik affair. The organization should also consider making an unambiguous statement of its position on evolution, intelligent design and creationism to reconfirm its credentials as a serious scientific body. In the past, TÜBİTAK has provided reliable information on Darwin's theory in a country where creation is offered as an alternative to evolution in high-school biology teaching. The agency could do that again. After all, none of the world's religions commands its believers to be creationists. Many Islamic scholars and thinkers have speculated on the origins of life.

Turkey's ruling party must learn from this latest affair. It must keep religion out of science policy, and be seen to be doing so.

\section{Health highway}

\section{President Obama's funds for electronic health records should prompt research - and controversy.}

( ne of the most striking, if little noted, aspects of the recent US stimulus bill is that 53 of its 407 pages are devoted to setting up the administrative framework for a national system of electronic health records (EHRs). At the head of this framework, which encompasses committees on standards, policy and much else, will be a National Coordinator for Health Information Technology, located within the Department of Health and Human Services.

Many will find it even more remarkable that this portion of the stimulus bill builds upon foundations laid by former president George W. Bush, who established the office of the national coordinator by executive order in 2004, and set him the goal of giving every American access to EHRs by 2014. Now, with the stimulus bill, Congress and the Obama administration have not only embraced that goal, but have allocated $\$ 19$ billion to help reach it.

Better still, from the research perspective, the stimulus bill explicitly envisions scientists being able to use these clinical records for a wide variety of population studies - monitoring the spread of flu, tuberculosis and other diseases, for example, or spotting people who might be good candidates for clinical trials, or looking for signs of adverse reactions after a drug has been released on the market (see page 278).

Many researchers believe that such studies could ultimately produce benefits as least as big as the effects of electronic records on clinical care - but only if some major issues about data access get resolved first. 
Imagine, for example, that Mrs Smith checks into the hospital for hip-replacement surgery. Her doctors will be able to call up the electronic records of her personal physician, her physical therapist, her pharmacist and everyone else who provides her with health care. But this scenario poses some knotty questions. Even leaving aside the technical challenge of securing all those far-flung databases against attacks by hackers, who has the right to access any given database? And how much are they allowed to see there - everything, or just those portions of the data they need for their jobs, keeping the rest private? And who decides? Patients? Doctors? Hospitals? Anonymization and pseudonymization, in which identities are masked but all data can still be ascribed to respective individuals, protect individuals while enabling research, but how should such measures best be implemented?

These questions have been contentious even in the United Kingdom, which has deployed an electronic records system through its unified National Health Service. They will be even more contentious in the United States, where the health system is anything but unified, and where privacy concerns run deep.

The scientific questions are just as knotty. For example, will each patient have to give permission each time a researcher wants to access his or her records? That sounds reasonable - and indeed, this is the spirit of the strict data privacy and security provisions of the federal Health Insurance Portability and Accountability Act. But that would make using the records for, say, routine epidemiology prohibitively cumbersome. There needs to be a clear policy allowing for such uses, as long as the researchers have no access to any aspect of the data that reveal a person's identity. But at the same time, the healthrecords system should provide individuals with an audit trail that shows them who has been looking at their records, and what they have seen there.

Or consider another scenario: a research group that wants to do a study aggregating EHR data over a large area. Will they have to get approval from every Institutional Review Board (IRB) - which oversee all research on human subjects in the United States - in every hospital and university involved? Common sense suggests that one IRB process is enough - and then only if the research uses personally identifiable data. But mechanisms to coordinate the oversight will have to be created.

The national coordinator and his advisory committees will have their hands full with these and many other issues. But the good news is that a management framework is in now place to address them, and to build an EHR system that will have the confidence of professionals and public alike.

\section{Filling the void}

\section{As science journalism declines, scientists must rise up and reach out.}

S cientists at CERN, Europe's particle-physics laboratory near Geneva, Switzerland, opened the wine last week to celebrate the twentieth anniversary of the laboratory's invention of the World Wide Web. The scientists were also joined by around $60 \mathrm{mem}-$ bers of the media, who may have been in a less festive mood. Even before the current economic crisis, the web was inflicting much pain on the mass media. Circulations have dropped, advertising has dried up and newspapers have been forced to lay off reporters and scale back coverage. A similar slump has hit the broadcast market, with no end in sight.

Science journalism is one of the numerous casualties in this media meltdown. Many science journalists are losing their jobs, and those who remain are being asked to provide content for blogs, podcasts, online videos and other new media (see page 274). Although it is difficult to know what effect these cutbacks have had on the public's understanding of science, the general feeling is that the quality of science coverage in the conventional media is declining - as is the media's ability to play a watchdog role in science, ferreting out fraud or other misconduct.

True, there is no shortage of scientific information on the web. Witness the way that research funding agencies use the web to inform the public about everything from planetary missions to public health. In principle, anyone with an Internet connection now has access to more, and better, scientific coverage than ever before.

In practice, however, this sort of information reaches only those who seek it out. An average citizen is unlikely to search the web for the Higgs boson or the proteasome if he or she doesn't hear about it first on, say, a cable news channel. And as mass media sheds its scientific expertise, science's mass-market presence will become harder to maintain.

Harder, but not impossible. For example, scientists are blogging in ever increasing numbers, and the most popular blogs draw hundreds of thousands of readers each month. These blogging scientists not only offer expertise for free, but have emerged as an important resource for reporters. A Nature survey of nearly 500 science journalists shows that most have used a scientist's blog in developing story ideas. And a handful of universities, meanwhile, have started environmental publications that are run jointly by scientists and journalists. These publications seek to provide their journalistically valid, scientifically accurate content free of charge to the mainstream press.

Sadly, these activities live on the fringe of the scientific enterprise. Blogging will not help, and could even hurt, a young researcher's chances of tenure. Many of their elders still look down on colleagues who blog, believing that research should be communicated only through conventional channels such as peer-review and publication. Indeed, many researchers are hesitant even to speak to the popular press, for fear of having their carefully chosen words twisted beyond recognition.

But in today's overstressed media market, scientists must change these attitudes if they want to stay in the public eye. They must recognize the contributions of bloggers and others, and they should encourage any and all experiments that could help science better penetrate the news cycle. Even if they are reluctant to talk to the press themselves, they should encourage colleagues who do so responsibly. Scientists are poised to reach more people than ever, but only if they can embrace the very technology that they have developed. 